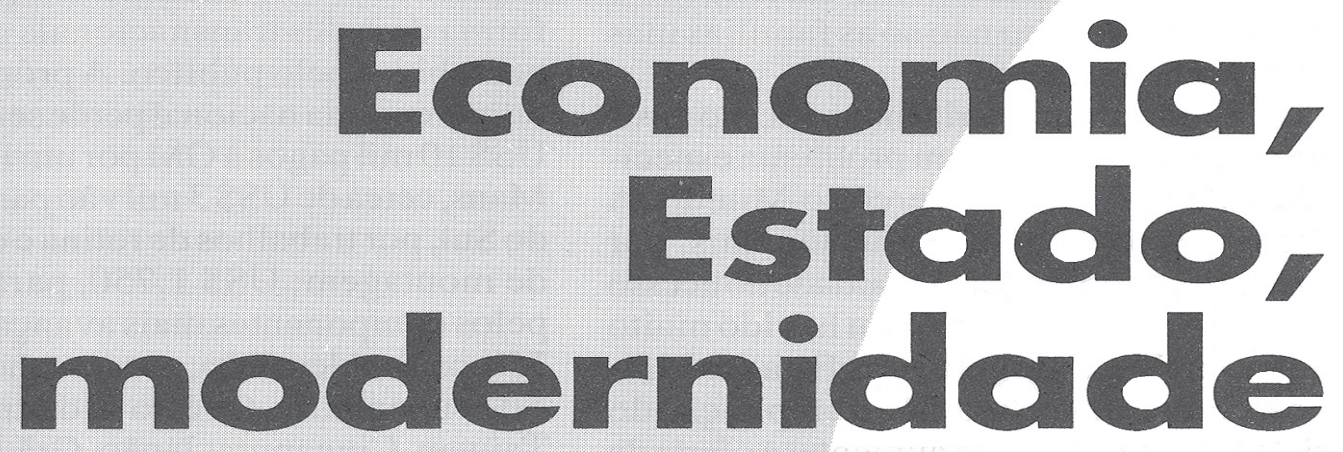

Uma crítica liberal

Dos grandes países da América Latina, o Brasil é o único que não chegou a decidir-se por uma integração mais completa na economia internacional e pela adoção de uma economia de mercado mais livre e menos tutelada pelo Estado. Foi pouco além de uma retórica da "modernização" que não se traduziu em uma ação concreta eficaz, e que qualquer perturbação do quadro político ameaça com um refluxo da maré ideológica dos anos 60 e 70.

A situação reflete, naturalmente, a imensa complicação do próprio país. Por um lado, é uma grande economia moderna cercada por uma periferia de Terceiro Mundo favelado, grandes massas subqualificadas e subocupadas, mal sobrevivendo, às vezes, ao nível do biológico. Por outro lado, essa 


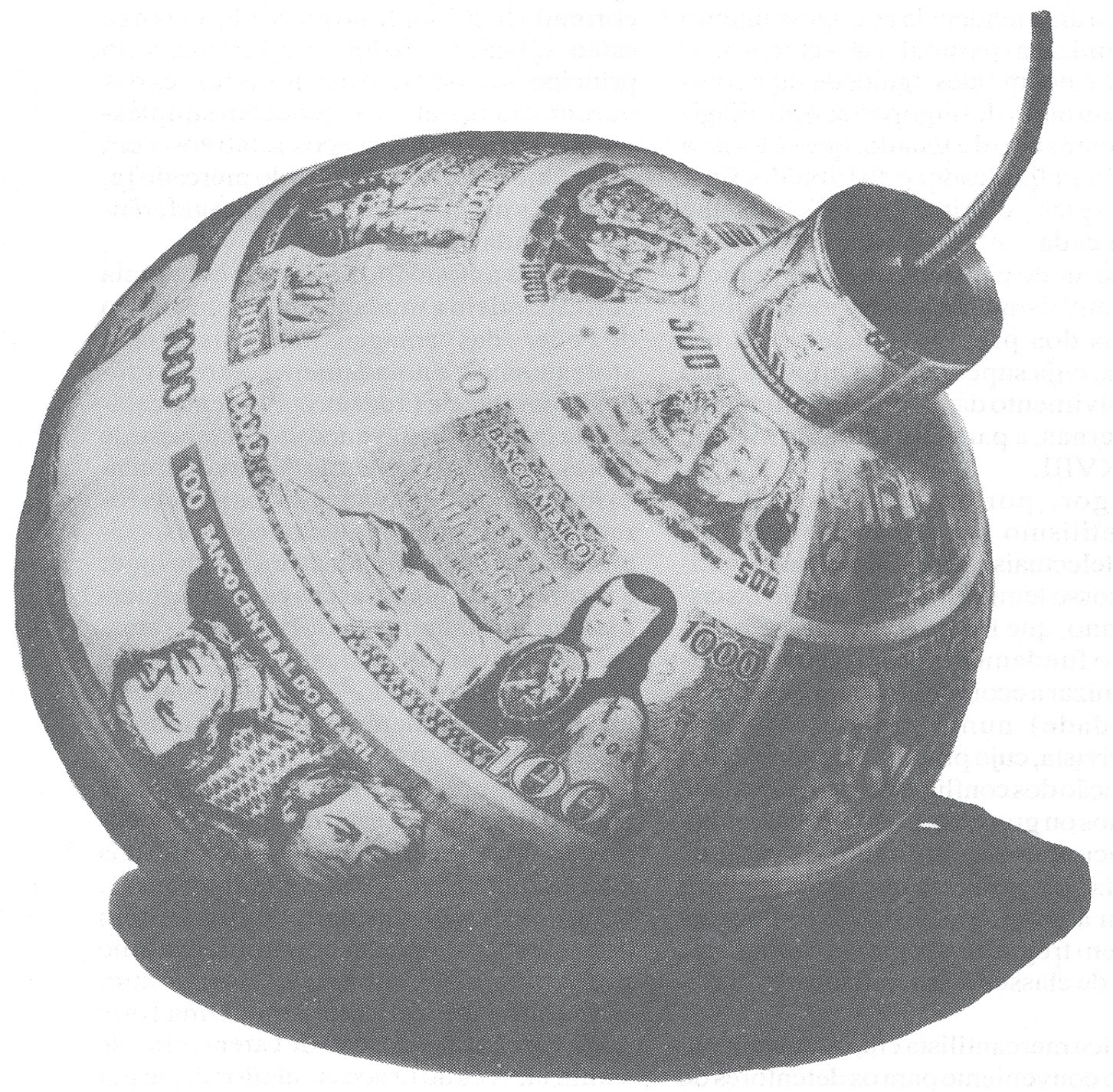

ROBERTO CAMPOS é economista, tendo sido responsável pelo Programa de Metas do governo JKe ministro do

Planejamento do governo Castello Branco. É autor de vários livros, entre eles, o mais recente, Reflexões do Crepúsculo (Editora Topbooks).

\section{OSCAR LORENZO} FERNANDES é economista, tendo sido embaixador do Brasil na Alemanha. E autor do livro Evolução da Economia Brasileira (Editora Zahar). 
economia moderna é algo de especial, de certo modo configurada para uma fase do passado já esgotada, desde as concepçôes de nacionalismo autárquico do fascismo dos anos 30 , à industrializaçío por substituiçâo de importaçōes, até meados dos 60 , sob a direçấo do Estadoe em condiçôes de extremoprotecionismo.

Esta sobreposição de características resulta em uma tendência aoengessamento da cconomia, cm particular do setor produtivo, dentrodos moldes rígidos de uma complicada estrutura de oligopólios e privilégios sob o comando do Estado, que se torna o irrecorrivel adjudicador e distribuidor final das vantagens, direitos e privilégios que cabem a cada um. Esse estado de coisas parece-se muito com um retorno às práticas do mercantilismo, típico das monarquias absolutas dos primeiros séculos da era moderna, cuja superação foi imposta pelo desenvolvimento das economias industriais modernas, a partir da segunda metade doséc. XVIII.

A rigor, porém, essa espécie de "mercantilismo subdesenvolvido" $1 \mathrm{em}$ raízes intelectuaise ideológicas mais próximas do nosso tempo, inspiradas pelo fascismo italiano, que fez do Estado forte o instrumento fundamental com o qual procutou organizar a economia (a bem dizer, toda a sociedade) numa grande estrutura corporativista, cujo princípioorientador era a eliminaçãodos conflitos de interesses entre individuos ou grupos sociais. Pressupunhase (e procurava-se atingir) uma espécie de harmonia universal, em que todos teriam o scu lugar assegurado, ao invés da concorrẻncia sem trégua dos regimes capitalistas e da luta de classes do socialismo revolucionário.

A ótica mercantilista era, evidentemente, muito conveniente para os detentores do Poder e o seu sentido inicial foi, de fato, promover a grandeza e o enriquecimento do Estado, mais essencialmente em função do Soberano - nāo do Estado no sentido de instrumentoda sociedade. Écscusadodizer que isso era ainda mais conveniente para todas as variadas clientelas do Poder, para as burocracias, para as sucessivas camadas de privilegiadose beneficiários das benesses do Soberano. Como o Poder é, pela sua lógica interna, monopolista, presta-se naturalmente à criação de estruturas hierarquizadas de privilégios, $\mathrm{cm}$ forma de "ảrvores". Nāo há diferenças essenciais entre os fenômenos que conhecemos da
Nomenklatura soviética e os inúmeros abusos típicos dos regimes autoritários ou despóticos do Terceiro Mundo(ou outros).

O liberalismo político surgiu do questionamento da legitimidade do poder absoluto dosoberano, cumséculo mais tarde Adam Smith lançaria as bases da teoria econômica moderna sobre o suposto da igualdade e liberdade individuais. Concorrendo livremente no mercado, elas nâo estấo sujeitas ao predomínio da vontade do príncipe ou às sempre tortuosas razões das burocracias estatais. Obedecem simplesmente à lógica dos preços relativos (um dado objetivo e automático do mercado) c, é claro, às próprias informaçóes e preferências de cada um.

Todas as transformaçôes na economia correspondem a mudanças na distribuiçâo do Poder $\mathrm{e}$ das vantagens materiais entre os atores sociais, e notadamente entre os grupos dominantes. Odesenvolvimento capitalista implicou no avanço de uma classe de atores, a burguesia. Mas nodesenvolvimento industrial mais avançado, os papéis foram ficando mais complexos com a especializaçẩo c com a urbanizaçāo, dando lugar à formação de gigantescas camadas intermediárias altamente qualificadas, as classes médias características das sociedades do "Primeiro Mundo", mas já numericamente muito ponderáveis no setor "moderno" brasileiro.

Uma parcela importante de um país como o Brasil ainda está, nocntanto, vivendo $\mathrm{cm}$ outra realidade, fora do tempo das naçổes industrializadas contemporâneas. Continua ruma realidade "antiga", com características herdadas do patrimonialismo portuguès via Colônia: cartorialismo, corporativismo, clientelismo. Uma forte participação quantitativa de carentes faz-se sentir, através do processo eleitoral, $\mathrm{cm}$ um populismo imediatista de esfaimados, ou num discurso distributivista liderado pelas parcelas ressentidas da intelligentsia c ideologicamente ligadoàs esquerdas do periodo de 30 a 60.

O quadro brasileiro nâo chega a ser original. Na realidade, é representativodos países em desenvolvimento depois da Segunda Guerra Mundial. Oque, porém, de certo modo constitui uma especificidade própria sảo, conforme o que já referimos inicialmente, as imensas dimensöes do pais e, portanto, a abrangência das suas contradiçôes: uma grande sociedade "moderna", com uma economia industrial avançada, 
ilhada dentro de uma cnorme periferia miserável, um gigantesco "pátio dos milagres". As diferenças entre as situaçöes con. cretas sīo de tal ordem que nuito mais fácil ć justapor as formas de cncará-las, as atitudes sociais, do que tentar reduzir as realidades que formamo grande mosaico nacional a denominadores comuns.

Una percepção "autêntica" da reali. dade do país pode ser, assim, muito ilusóriat. Mas já houve momentos en que isso pateceu bastante menos complicado, quando projetos assumidos pelas fraçôes decisivas das elites brasileiras ganharam status de opçōes "nacionais". O de Juscelino Kubitschek é dos exemplos nais interes. santes. Tem suas raizes em Vargas, mas se torna tâo representativo da mancira de ver opais, conoum todo, e tâu "modernizicher", no seu nomento, que fundiu o mokte que continuaria a ser basicamente usado peles sovernow da fase antoritiria pox-196-

Os problemas dessa ć poca pareciam, no entanto, mais fáce is. Imaginava-se que a incorporação ao mundu "moderno", sob a forma de industrializaçâo c urbanizaçăo, por si só diluiria o atraso do "país rural" numa contempotancidade concebida com poucos clementos ambiguos. Náo se pensou que uma demografia descontrolada de áreas primitivas pudesse inviabilizar ofácil modelo"desenvolvimentista"-mesmo porque, no início dos anos 50 , esse fenômeno nảo estava sequer bem identificado no cenário internacional. Desde então, entretanto, uns 100 milhóes de pessoas subqualificadas, mal nutridas e carentes foram adicionadas a uma população urbana que, no começo, pouco passava de 18 milhōes.

Uma parte atuante das nossas elites intelectuais (como na América Latina e no Tercciro Mundo) situou-se, entāo, em posiçóes "progressistas" muito marcadas pelas linhas de esquerda do final do período stalinista, quando muitos sentiam como um dever cooperar com a estratégia soviética no conflito ideológico-militar com obloco "capitalista" liderado pelos Estados

Unidos. Essas posiçôeseram tanto mais compreensiveis, entho, quantopareciam continuar a luta contra o nazifascismo, que levara àtática da cooperação nas "Frentes Populares", $c$ quanto, alćm disso, as potências coloniais curopcias, com oapoio um tantodúbio, mas desastrado, dos Estados Unidos, ainda procuravam, até por volta dos anos 60 (sem grande cntusiasmo, aliás), retardar os movimentos de libertação nacional nas áreas sobscu domínio.

Com a soluçāo do conflito do Vietnă desfavorável aos Estados Unidos, no começo da década de 70, e com a longa e crucial crise cconômica mundial dos anos 71 -73 a 82-85 (ainda nâo resolvida de todo para os países socialistas leste-curopeus e para numerosos do Terceiro Mundo), essas posiçōes dos anos 50 estariam necessariamente "datadas", Mas as formulaçôes ideológicas parecem resistir muito às práticas racionais de depreciaçấo amortizaçı̆o. Ou. em todo caso, este é, pelo menos, um dado da experiéncia brasileira talvez, quem sabe, porque o hiato autoritário de 1964 a 1985 terácontribuidopara preservar ao longo des. se tempoo instantânco que retratava as posiçōes políticas $\mathrm{c}$ as idéias no início dos anos 60 .

Atualmente, com a experiència adquirida do descalabroc, por fim, do dramático desmoronamento do"socialismoreal"sovićtico cleste-curopeu, assim comoda penosa realidade da inépcia catastrófica, da brutalidade, da corrupçáo e, antes de mais nada, da intratável irracionalidade de grande parte dos países menos descnvolvidos, temos talvez certa predisposiçáo a fechar, coms $\mathrm{um}$
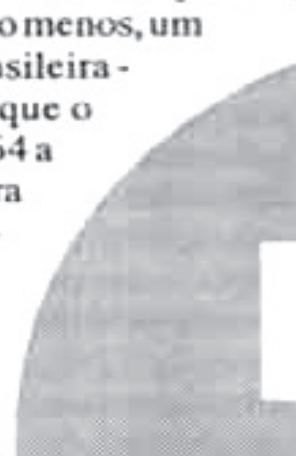
livro já lido, o periơo de umas duas geraçôes que vai da desagregação da velha ordem liberal de antes da Primeira Guerra Mundial até a crise dos anos 70-80. Entretanto, nesse periodo, não devemos esquecer, chegaram à fruiçẳo final noçōes que haviam começado a deitar raízes com o advento da era moderna c tomado forma já no final do séc. XVIII. quando o homem começava a crerque penleria vir a alcançar. cm relaçáo ao seu universosocial, o mesmo grau de dominio que a ciéncia e a técnica já The estavam proporcionando sobre o universo da natureza - um domínio nāo mais como "utopia", conforme se projetara desde a antigüidade clássica, mas como relaçio ficiente, como "engenharia", na visâo caracteristica de Saint Simon.

O mundo clássicu concebia o herói mitico, c o Medicvo ocidental imaginava a intervençâo do sobrenatural, intermediada pelosanto. Nos negócios humanos, admitia a possibilidade do "bom governante". Mas este se distinguiria pela virtude, nāo por alguma competência abstrata, como se espera, hoje, doadministrador eficiente. Nem haveria, de resto, muito escopo para isso numa cconomia basicamente agrária, com algumas adiçōesmercantise artesanais. Para lanto, o conhecimento indispensável nĩo iria muito além doque se poderia esperar de um pater familias prudente.

Só noséc. XVIl é que a acumulaçâo do conhecimento cientifico começa adquirir caráter sistemático e aos poucos passa a fundamentar o que hoje chamariamos de "tecnologia", aumentandodramaticamente opoder que o homem principia a exercer sobre omundonatural. A física e a astronomia de Galileu, querendo-o ou nūo a Inquisiçảo-quem nảo se lembra de Brecht?"traduzem-se imediatamente na eficiência da artilharia e da navegaçắo oceảnica. Eas conclusôes seguem-se por si mesmas.

Nẫo muitodepois disso, opensamento político liberal (com L_ocke, cm especial) usa a Razão para questionar, como dissemos, a origem e a legitinnidade do Poder. E, đaí $\mathrm{em}$ diante, nāo seria uma questấo de muito tempo para que alguns passassem da indagaçăo sobre a ordem das coisas nil sociedade à disposiçấo de dar a esta mesma sociedade a configuraçăoque consideravam melhor. Este último passo implica, porém, um saltoalém dos limites da racionalidadc: oque é que pode legitimar a escolha de uma determinada configuraçio da sociedade, de preferência a outras quaisquer possíveis?
Observe-se que nas ordens sociais anteriores, a legitimaçẫo se fazia segundo critérios exógenos a elas - por tradição, por uma su posta decisão divina, por algum mito. Para justificar (e impor) uma ordem social por vía racional seria necessário definir e justificar previamente os critérios dos quais se derivasse essa conclusão. Mas, comoé fácil de perceber, isto reduz-se a uma cadeia interminável de elos sucessivos, cada qual empurrando para o próximo o argumento final. Emúltima ańlise, trata-se de valores que, enquanto tais, näo comportam uma prova teórica conclusiva. Em si mesmos. valores somente se podem inferir de outros valores, e nâo de proposiçổes lógicas.

Várias tentativas de soluçâo foram imaginadas para esse insidioso problema. Alguns procuraram construir regimescom valores baseados $\mathrm{em}$ conjuntos de valores que supunham majoritários, ou que thes pareciam justificados pelo senso comum. Outros simplesmente fizcram opçôesessencialmente voluntaristas $\mathrm{c}$ arbitrárias (o caso do fascismo italianocom a idéia da grandeza e glória do Estado, e o do nazismo com a precedência absoluta da comunidade de sangue). O socialismo de Marx julgou que havia desvendado cientificamente as leis dodesenvolvimento da História.

A corrente central do pensamento do Ocidente, mais influenciada pelas idéias liberais, evoluiu noutro sentido. Adam Smith, opai da teoria econômica moderna, procurou identificar de modo objetivo os fenômenos econômicos, em particular os comportamentos dos agentes com eles relacionados, determinandoregularidades e generalizando-as. Smith (além do mais, de inclinaçĩo filosófica) nâo chegaria, no entanto, acexageroque, uma centena de anos mais tarde, seus discípulos "neoclássicos" praticariam, a saber, procurar determinar no campo das ciências sociais, com métodos formalmente rigorosos, ogènero de leis universais que as ciências físicas estavam formulando com extraordinárioêxito. Determinar le is científicas constitui, é claro. um bom meio para, dentro do respectivo campo, influir no mundo real. O fato de os regimes "capitalist:as" estarem convencidos de que, ao seguirem as regras da economia de mercado, estavam apenas curvando-se à natureza real do mundo não deixava de fazer de seus esquemas teóricos um instrumento de ação sobre esse mesmo mundo.

Há, no entanto, uma diferença importante entre essas colocaçōes. A cconomia 
de mercado assenta-se sobre uma consulta permanente $\mathrm{c}$ ininterrupta às preferéncias dos indivíduos, que se reflete objetiva $\mathrm{c}$ automaticamente nos preços relativos dos fatores e produtos, nos níveis de consumo $\mathrm{c}$ poupança, c assim por diante. Náo é um processoà prova de efeitos tendenciais nem đe imperfeiçōes várias e, por isso mesmo, náo exclui a eventual necessidade de medidas corretivas por parte da sociedade. E $\mathrm{nem}$ todas as interaçốes ou transaçōes efetuadas dentro do espaço social podem ser propriamente "de mercado". Numero. sos bens, pelasua natureza, tě̉m de ser ofe. tecidos por intermédio dosetor público.

Por outro lado, todas as concepçóes cconômicas baseadas no controle da sociedade através dos mecanismos do Podernegam, a priori, a precedència da liberdade individual. Pelo contrário, pressupōem necessariamente a sobreposiç̣̂́o de alguma instância intermediária que determina, acima e além dos desejos e preferèncias das pessoas, aquilo que será melhor para elas.

Isso nâo parecia tâo sério no auge da llustraçâo, quando a concepçáo de que o homem era um ser naturalmente bom, eventualmente corrompido pela sociedade (tipificada por Rousseau), parecia náo deixar dủvida quanto à superioridade da açăo política racional sobre as formas tradicionais da autoridade, mesmo do despotismo esclarecido. Saint Simon (o avô de Marx. por assim dizer) imaginava a sociedade governada autoritariamente por uma tecnocracia meritocrática. Mascomoos anos do fascismo iriam penosamente demonstrar mais de um século depois, não há garantiaalguma de excelência norecrutamento dessas elitestecnocráticas.

Para um homem da Idade Média, do Renascimento, ou mesmo ainda do séc. XVIII, no Ancien Régime, o Estado, na nossa acepçảo atual, conccitualmente muito abstrata e diluída, não seria objeto de discussão. Pensava-se em termos maisconcretos c, por isso, náo faltava o realismo para julgar obom co mau soberano. A abstraçío extrema era reservada para outros tópicos insolúveis (como nos séc. XVI c XVII, a teligiño" verdadeira") atéque, Iendo-se esgotado boa parte da Europa $\mathrm{cm}$ guertas religiosasque nãoserviram para dat hegemonia aos Habsburgos católicos do Império e das Espanhas, o Norte protestantizado foi tratar de outras coisas, deixandoo Sul católico às distraçôes doseu atraso material c cientifico. Naturalmente, também hoje praticamos distinçōes entre bons $\mathrm{c}$ maus governos (complicando, talvez, a sólida simplicidade do sentido comum dos velhos Iempos com camadas sucessivas de jargảo sociológico, antropológico, de comunicaçīo, e mais lá quanto nos ocorra). Inquanto isso, abstraçōes como "Estado" (um conceitorelativamente novo, em termos históricos, um universal que é apenas uma casca teórica vazia, à espera do conteúdo semàntico que nela se despeje) sâo usadas quotidianamentc com o maior desembaraço polémico, como se de fato estivessem cartegadas de sentido conereto$\mathrm{c} \mathrm{cm}$ torno delasé que se focalizam muitas dasdisputas idcológicas.

Na verdade, a noçáo de "Estado" tornou-se orepositóriode uma série de caracteristicas funcionais abstratas, uma cesta na qual se recolhem conceitualmente todas as funçōes que se supóem fundamentais para a operaçáo do sistema social, com seus subsistemas político, econômico, etc. Osalto ilegítimo, que se dá geralmente camuflado. a hipóstase, consiste em deixar subentendida a existência de um ente real correspondente ao abstrato. Eessa questảo tem sido notadamente complicada nas sociedades economicamente menos desenvolvidas. onde a necessidade de entender o processo, de dispor de categorias de interpretaçăo, é mais acentuada, e pode chegar ao ponto da exasperaçio.

Assim, por serdescarnado e absirato, 0 "Estado" assume certas caracteristicas próprias de nox̧óes das disciplinas exalas (como seriam "ängulo", "reta", etc.), conccitos sobre os quais se pode discutir metodologicamente indefinidamente, mas de que nảo se podem postularvaloresexistenciais. Um"ângulo injusto" ou uma "integral desonesta" seriam, quando muito, humorismo. Mas nem mesmo Weber, na sua análise da burocracia e da racionalidade de fins e de meios, mostrou-se suficientemente alerta para esse insensivel deslizamento desde o espaço virtual da abstração do universal em direção ao espaço do real do mundo existente.

As formulas de controle diretoda sociedade econômica através dos instrumentos do Poder pressupöem inevitavelmenteque possam ser criados e operados eficientemente mecanismosque determinem oque cada agente econômico tem de produzir e quanto deve receber, que processos serío utilizados, como serio coletados e acumu. lados os recursos destinados aos investi- 
mentos, e assim por diante. Decerto, o grau e a minuciosidade da açăo desses mecanismos podem variar segundo um amplo leque, indo desde um autoritarismo mais ou menos tópico até a regulaçâo praticamente total.

Num plano puramente teórico, poderse-ia perguntar por que decisôes conscientes de agentes do Estado haveriam de ser menos racionais e menos eficientes doque as decisōes descentralizadas tomadas espontaneamente por mecanismos automáti$\cos$ (c, nesse sentido, mais ou menos "cegos") do mercado. À primeira vista, pareceria que, no primeirocaso, o acerto médio das decisôes deveria ser superior ao dosegundo - istoé, uma economia mais "socializada" seriit, em tese, provavelmente algo mais racional e eficiente do que uma "capitalista". Eraessa, aliás, a convicçáo de Lênin c seus companheiros, na Revolução soviética. Von Mises, como se sabe, numa famosa polèmica por essa época contestou a viabilidade de uma economia socialista, baseando-se na impossibilidade de resoluçầo đo gigantesco número de equaçōes simullâneas necessárias para a determinação dos preços de equilibrio de todos os fatores e produtos (o que é facilmente perceptivel quando se imaginam as dimensōes de um sistema walrasiano correspondente a uma grande conomia industrializada).

O argumento nunca foi contestado satisfatoriamente, embora não fosse inconcebivel imaginarem-se meios de solução tais como, meio século depois, o advento dos modernos supercomputadores poderia parecer tornar possível. Mas, na verdade, apesar da brilhante análise de von Mises, a viabilidade (ou não) do cálculo econòmico nâoera, de fato, oproblema central. Este era outro, e residia na própria natureza do Estado, que nîoera, nem poderia ser, uma estrutura abstrata puramente lógica, capaz de aplicar sem quaisquer vieses ou distorçỏes os paradigmas que thes fossem dados para tal fim. Muito pelo contrário, o Estado é integrado por individuos, organizados de maneira geraimente muito pouco eficiente, com interesses próprios de que costumam ter uma consciência bastante nítida c intensa.

Além disso, nāoé teoricamente válido falar-se cm "interesses gerais". E por uma razảo lógica muito simples: falar $\mathrm{cm}$ "interesses gerais" constitui apenas uma forma reduzida de dizer que existe um método com o qual podemos definir um algoritmo que nos leva a determinar um resultado final que chamaremos de "interesses gerais". Quando um astrônomo menciona um quasar, por exemplo, o que está fazendo é dizer de modo condensado que ele usou determinados métodos para definir os algoritmos que, aplicados às observaçôes feitas, the permitem afirmar que certos resultados constituem aquilo que ele chama de "quasar".

Da mesma forma, no que se refere a uma sociedade, a uma economia concreta, "interesses gerais" significam apenas, na realidade, aquilo que determinadas estruturas (instituiçōes, burocracias, individuos imbuidos de suficiente poder, etc.) dizem que săo tais. Essas estruturas podem ser, é claro, integradas por pessoas altamente motivadas e sérias, altruístas e embebidas nos valores mais altos da sociedade - $\mathrm{e}$ podem, também, ser o inverso, uma coleção de canalhas. É muito provável, aliás, que, quanto menos "desenvolvida" $\mathrm{c}$ menos integrada scja uma sociedade, maior seja o risco de que canalhas, oportunistas $c$ espoliadores tendam a ocupar os postos de controle (uma vezque é nestes que melhor terỉo como satifazer aos seus próprios egoísticos interesses). Mas a essência da questăo nâo reside $\mathrm{cm}$ climinar os mause. no seu lugar, colocar os bons - mais ou menos, mutatis mutandis, o problema do déspota esclarecido noséc. XVIII. A verdadeira soluçīo deste problema nâo foi dada pela procura de bons déspotas (que, claro, seriam preferiveis aos maus), mas pelos métodos do liberalismo político, com a eliminaçáo do despotismo pela democracia representativa. É possível que os regimes democráticos, em contraste com obrilhoc as elegantes manciras do Ancien Régime (comooconvictodemocrata de Tocqueville certa vez sugeriu com uma ponta de melancolia), parecessem medíocres e sem galas do espírito, mas cram a soluçĩo.

O mundo pós-1946 manteve-se, durante $\cos 25$ anos da "Pax Americana", num regime econòmico com uma boa base de mercado, mas não exatamente "liberal" antes, numa condiçâo de "liberdade vigiada". A crise de 1971-73/1982-85 demonsIrou dramaticamente as limitaçōes das politicas de intervençāo corretiva, de "sintonia fina", mesmoem relaçãoàs economias mais "sofisticadas". A concorrência, a disputa dos agentes econômicos na imensa arena do mercado, de modo algum garante os resultados mais belos ou mais nobres, e nem 
sempre, sequer, os mais eficientes(inclusive porque tende a ter um viés contra as consideraçōes de longo prazo, e contra os bens e serviços de natureza pública).

Mas compensa esses inconvenientes com o fato de que está sempre com os ouvidos atentos para o ininterrupto plebiscito das preferências que o mercado expressa. Para algumas pessoas, os resultados podem parecer de uma sabedoria discutível, e até desastrosos (problema que também ocorre com as escolhas políticas no processo democrático). Mas para ísso nảo há mais re. médio senâo a sedimentaçẫo dos valores sociais com o tempo.

Operíodo "liberal", em que a cvoluçî̀o política e econômica coincidiu para uma expansão cada vez maior das liberdades individuais, duraria um século, doqual dois terços (digamos, de 1846 a 1914) foram a sua época "clássica": a liberdade de comérciode mercadorias e de movimentação internacional de capitais e de pessoas, a crença no progresso ilimitado da ciência c da técnica, das artese da sociedade, a acrítica confiança na "civilizaçăo" do Ocidente. Mas essa ordem de coisas nấo resistiria à Primeira Guerra Mundial. E nảosó porque o choque em si mesmo foi brutal (um décimoda populaçĩo curopéia morto em quatro anos), mas porque tudo parecia incompreensível, como se todo o edificio da cultura e dos valores desmoronasse, de repente esvaziado de qualquer sentido. Chega a haver um verdadeiro delírio de irracionalidade, tipificado, $\mathrm{cm}$ grau cxtremo, pelovoluntarismo fascista.

Revoluçōes comunistas (êxito na Rússia, insucesso na Alemanha e Hungria). violência fascista alastrando-se infecciosamente pelo mapa mundial, uma ingênua tentativa, sob patrocinio americano, de redesenhar a geografia política com a Liga das Naçōes, início da agitaçấo đe independência nas colônias. Começa a perceber-se que, com a aglomeração de soberanias nacionais absolutas, se exasperavam as contradiçōes entre a segmentaçẩo do universo político e a universalidade da ordem econômica, mas nenhum caminho parecia levar à cooperaçâo racional: depois de 28 reuniōes internacionais importantes entre 1919 e 1933, o mundo acabaria, com ofracasso da Conferência Econômica de Londres, neste último ano, compartimentado $\mathrm{em}$ blocos monetários mal comunicantes, comocomércio internacional estrangulado c emplena depressấo.
As contas nâo liquidadas depois da Primeira Guerra Mundial foram retomadas aofim daSegunda, inicialmente, comodissemos, num regime de "liberdade vigiada", 1946-1971, que, por sua vez, se esgotaria na demorada crise de 1971-73 a 1982-85. Neste último ano, sistematiza-se a cooperação regular do G7, o grupo das maiores potências econômicas do mundo ocidental c, em 1987, uma grave quebra das Bolsas internacionais, inicialmente duas vezes mais violenta do que a de 1929, é rapidamente contornada graças ao entendimento entre as autoridades financeiras das principais economias de mercado.

Por outro lado, a desagregação dos regimes socialistas do Leste curopeu e, logo depois, da UniâoSoviética, no final dosanos 80, fenômeno histórico realmente extraordinário peloseu caráter pacíficoe unânime, surpreende o mundo com uma despolarizaçăo ideológica instantânea. De um momento para outro, o que parecera, durante duas geraçốes, o caminhoalternativo socialista da reconstrução do mundo c do homem, restou apenas comocrença residual de regiōes subdesenvolvidas, nấo de todo diferente dos fundamentalismos religiosos.

Depois da Primeira Guerra Mundial, nos países maisavançados, governos e agentes econômicos, perplexos diante da imprevista violéncia dos surtos inflacionários $\mathrm{e}$ recessivos, dodesempregopersistente edos desequilibrios do setor extemo, recairam em tendências nacionalistas c populistas, recorrendo a medidas particularistas que, interferindo umas com as outras, não podiam senâo agravar, no conjunto, os males que se destinavam a corrigir. Isto foi, como dissemos, parcialmente resolvidodepois da Segunda Guerra Mundial, mas os países em desenvolvimento, como um todo, ficaram mais ou menos à margem do processo, e é compreensivel que se sentissem tentados pela incbriante esperança de tomar nas próprias mãos as rédeas doseu desenvolvimentoc, por conseguinte, pelas propostas anti-liberais - nåosódas esquerdas mas (talvezainda mais mareadamente) das múltiplas versões do fascismo, que ainda exerciam uma atraçảo intensa sobre os segmentos militares e tecnocráticose, é claro, sobre parte das forças mais tradicionalmente conservadoras).

Também, nos anos seguintes à Primeira Guerra Mundial, as preocupaçōes sociais assumiram uma importância crítica. Sua origem achava-se em uma das linhas 
evolutivas do pensamento liberal na segunda metade do séc. XIX, quando os conirastes entre a miséria das massas trabalhadoras inglesas com a acumulaçâo da riqueza no topo da sociedade (apesar da evidência de um progressivo aumento dos padrōes de vida, cm geral) provocaram amplas reaçōes religiosas, éticas e políticas. A Alemanha de Bismark adiantara-se estabelecendo. duas décadas antes do final do século, o primcifosistemia de seguridade social com cobertura universal. Masa brutalidade das flutuaçôes da Renda c do emprego, após 1918 , iria mostrar que os custos humanos dos mecanismos economicos de ajustamento automático já nâo mais eram politicamente aceitáveis.

Os paises menos desenvolvidos, depoisda Segunda Guerra Mundial, assimilariam essas novas demandas sociais tanto mais facilmente quanto, pela sua própria condiç̣̂o económica, tinham consciência de suas enormes carências materiais, por comparação com as condiçôes dos países "ricos". Ea influêtncia dos paradigmas de esquerda, neste caso, era absorvida com pouca dificuldade, porque Marx (com una importante mas mal conhecida exceçio, à qual já nos referiremos) nunca chegou a dar importância ao fenómeno da escassez, c situando a origem de todos os males do capitalismo na má distribuição dos meios de produçĩo.

Os regimes socialistas tinham algomais a oferecer, a promessa de uma fórmula capaz de transformar o mundo - cmbora, já entâo, a Uniño Soviética, sob Stálin. houvesse abandonado as idéias da revoluçio universal. Os dados docrescimento conômico sovićticocram, nesse tempo, impressionantes - de tal ponto que Khruschev, no começo dos anos 60, ainda podia prever, com absoluta seriedade, que a URSS superaria o produto interno dos Estados Unidos atć o fim do Segundo Plano Septenal (em 1972). O esquema teórico cra simples c, aparentementc, da maior racionalidade: com o controle dos meios de produção nas mãos do Estado(istoé, da "classe trabialhadora"). era possivel fazer um grande esforço de formaçấo de cupital (independente de consideraçöes imediatistas de rentabilidade), concentrando investimentos nos setores da "reproduçäo ampliada" (máquinass, equipa. mentos, produtos de base, insumos críticos). Esse esquema parecia encontrarapoio em certos aspectos das idéias keynesianas (que, por sua vez, por Irès décadas a partir de meados dos anos 30, davam a impressāo de ter suplantadoa ortodoxia econômica do "capitalismo").

Somente por volta dos anos 70 é que se começou a generalizar (a partir, primeiro, da experiência de alguns países altamente industrializados, como Inglaterra e Estados Unidos, mas também, subsidiariamente, pela observaçio do insucesso das políticas de desenvolvimento do Terceiro Mundo, $\mathrm{c}$ pela evidẻncia das dificuldades crescentes e da ameaça de estagnaçío das economias socialistas do Leste Europeu e da União Soviética) a compreensão de que poderia existir um enorme hiatoentre a racionalidade abstrata de que, em teoria, se supunha capaz. o Estado contemporainco, c a realidade comprovada da sua reduzida eficácia empirica.

As esquerdas marxistas relutariam muito a accitar esses fatos. Marx imaginara a "expropriação dos expropriadores" como um processorelativamente simplesque, uma vez levado a cabo, climinaria a priori os conflitos de interesses entre os Irabalhadores, estabelecendo automaticamente entre cles uma perfeita fraternidade. Como seria administrada a nova ordem de coisas nāo the pareceu um problema merecedor de particular atençî́o-e Lènin, depois da Revoluçâo, como se sabe, muitas vezes resmungaria exasperadoque Marx deveria ter pensado em como deveria funcionar concretamente o socialismo. A possibilidade de uma degenerescência burocrática e de um fenomenode "novas classes", cmbora percebida ainda mesmoantes de Lênin, no final do séc. XIX, só foi retomada pelo rebelde iugoslavo Djilas, nos anos 50, e até muitorecentemente permaneceu totalmenIc antítema para a quase absoluta generalidade das esquerdas, um pensamento "antirevolucionário". Pelo contrário, oprestígio da grande empresa industrial capitalista, das formas "sofisticadas" de otganizaçâo gestâo, o desenvolvimento de técnicas matemáticas c estatísticas, da "pesquisa operacional", intensamente utilizadas na programação cconômica e militar desde a Segunda Guerra Mundial, pareciam indicar que os problemas de organizaç̃o e gerência cram fundamentalmente "téenicos" c nīo ofereceriam base real para criar privilégios no sentido de classe ou casta.

A exceção que Marx contemplou quaanto ao papel da escassez diz respeito, precisamente, à condiçāo dos "subdesenvolvidos": a persistiro"estadode escassez", afir- 


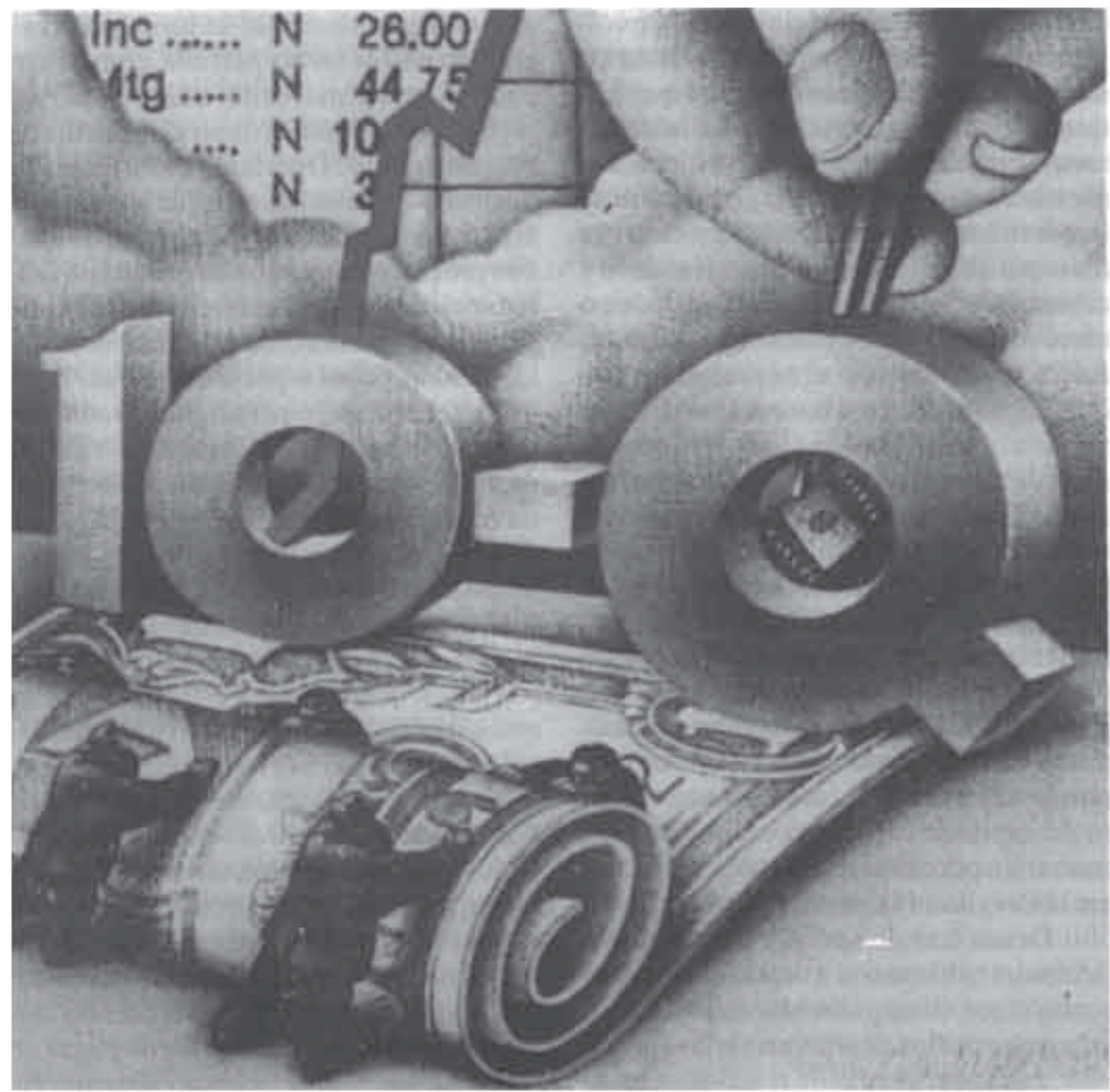

ma, pode-se fazcra adistribuiçâoque sequeira que continuará ludo no velho estado de coisas. Observaçăo infelizmente muito realista, mas que nẫo penetrou na consciência da maioria das sociedades menos desenvolvidas $\mathrm{cm}$ todos estes anos do apósguerra.

A frontcira do equilibrio entre a produçăo de riqueza e a sua distribuiçăoé sempre incerta. Seria uma falsa dicotomia equacionar a questáo em termos de uma coisa ou outra. Mas a produção tem, pelo menos, a prioridade da antecedência: não se pode distribuir o que não existe ainda.

Enâo há, infelizmente, nenhuma fórmula perfeita para a satisfação dos desejos e necessidades da totalidade dos homens em nenhuma sociedade. Enão há, porque a escassez ć uma condiçāo objetivamente inevitável e porque, além disso, os homens possuem disposições menos fraternas c altruísticas do que scria desejável, e competem entre si, disputando uns aos outros bens materiais c imateriais, posiçầ na es- cala social, poder, e tudo mais de que se possam apropriar de alguma forma.

Da centena de novos Estados em que sc dividiram as antigas áreas coloniais ao fim da Segunda Guerra Mundial, nâo muitos contam com as condiçōes indispensáveis para a criaça de economias realmente descnvolvidas, em particular dimensöes mínimas adequadas e uma base satisfatória de recursos naturais. Alguns apresentam condiçōes muitodesfavoráveis. Doconjunto dos paises "cm desenvolvimento", o Brasil ć o primeiro entre aqueles que reúnem a maior quantidade de fatores objetivamente propícios.

Quando falamos na ineficiência das formas de controle da economia pelo Estado, seria justo recordar, primeiro, que esse problema também se observou em economias de mercado altamente desenvolvidas; c, segundo, que a evidência dos países do Terceiro Mundo e dos socialistas mostra, também, casos de resultados positivos, de crescimento às vezes até muito rápido, prin- 
cipalmente nas fases iniciais do desenvolvimento econômico, em particular da industrialização. Oque se observa é que, enquanto os objetivos a atingir são relativamente poucos e simples, o desempenho é aceitável, mas que o Estado gerente começa a defrontar-se com dificuldadescada vez maiores à medida que vai aumentando a diversificação, o grau de complexidade c o nível tecnológico da economia, e que se torna mais critica a necessidade de integraçăo nosistema internacional.

E a cvidência of erecida pelas cconomias de mercado altamente industrializa das parece convergir no mesmo sentido: à medida que fornm assumindo responsabilidades por políticas econômicas de "sintonia fina", tentando otimizar, ao mesmotempo, os niveis de empregoe de preços c o equilibrio do setor externo, e que passaram a ter de administrar programas sociais muito ambiciosose abrangentes, essas economias nẫo só tiveram desempenho inferior às expectativas como, além do mais, acabaram por despertar reaçöes negativas em sctores dominantes da opiniāo pública.

Desde fins do séc. XVIII, o homem ocidental habituou-se a ver no Estado, por assim dizer, o braço secular da Razāo, e a supor que os fins desejáveis seriam racionais, e que oracional seria possivel. A identidade entre o Estado ideal c o empírico foi mais ou menos assumida acriticamente na visão do mundo dominante. Para aqueles que, de alguma forma, se sentiam marginalizados pelo processo histórico-certamente ocasodos países menos desenvolvidose dos socialistas (salvo quando o regime foi imposto por força externa) -, acreditar no supremo poder de transformar a sociedade pela Razáoconstituiu sempre uma tentaçăo prometéica difícil de resistir.

Em última análise, porém, como entendeu Brecht, a prova da realidade empírica acaba sendo a mais forte. Mas o ponto essencial da questấo náo se reduz a uma cscala de eficiencia de diversas alternativas de açăo do Estado. Ou antes, nảoésó (c talvez. nem principalmente) o problema da funcionalidade deste o que está em jogo.

Opontocentral é oda maximizaçãoda liberdade individual. Ou melhor, da harmonizaçăo entre liberdade e necessidade: o máximo de escolha e o mínimo de coerção do indivíduo, compativeis com o máximo de eficiência na satisfaçảo daquelas demandas sem as quais a liberdade individual vai se tornando vazia de conteúdo. $\hat{E}$ este compromisso que se torna possivel, embora nâo de forma perfeita, com os mecanismos do mercado como meio de regulaçăoautomática da produção e distribuição de bens. Operando sob a forma de um plebiscitocontínuo em que as preferências dos indivíduos se expressam através dos preços, o mercado não promete a felicidade universal, mas assegura o máximo simultâneode eficiência e de liberdade dentrodas condiçôes específicas dadas.

Infelizmente, o paradigma docontrole dodestinoda sociedade pela Razĩo esconde, porbaixoda sua aparéncia de libertação da condiçăo humana, o seu contrário, um sério fator de alienaçủo e auto-engano, de mistificaçĩo da realidade, que é tanto mais forte quantomais atrasada materialmente a sociedade em que é tomado por referência (ou antes, quanto maior o "coeficiente de escassez" nela embutido). E nâo é difícil entender por quê. Em toda sociedade, num momento qualquer dado, existe uma distribuiçâo determinada dos benefícios e privilégios por ela oferecidos, uma hierarquia de poder, prestígio-uma estrutura, enfim. Essa estrutura resiste às transformaçōes que sente detrimentais, faz alianças, associa-se, muda por dentro, sempre tentando minimizar o preço que possa ter de pagar no processo de modificaçấo do sistema. As classes dominantes sempre deram uma boa parte da intelligentzia contrária às instituiçōes - tanto da nobreza e da burguesia francesas do Ancien Régime ou da Rússia lmperial quanto da burguesia e das classes médias do'Terceiro Mundo atual.

Mas náoésó isso. As socicdades “atra. sadas" são também, por motivos vários compreensiveis, freqüentemente muitomal integradase corruptas - nāoraro, tendomuito poucode "sociedades" $\mathrm{c}$ mais de agloneraçōes com escassos pontos de referência comuns. Em tais condiçōes, ocorre facilmente a adoçẫo de capas ideológicas de pura aparência, inautênticase falsas, que servem para dar cobertura a interesses corporativos ou clientelísticos de alguma forma simbióticos com os grupos de interesses dominantes, ou a formas populistas que funcionam, de certo modo, como as distribuiçóes de alimentos e aos jogos circenses para satisfaçả̉o da plebe romana, o panem et circenses, na realidade anestésico, $\mathrm{c}$ nåo fator de câmbio real.

Conscientemente ou não, este tem sido o papel de muitos dos movimentos "progressistas", "nacionalistas" c "de esquer- 
da" no Terceiro Mundo, em especial em países de nível intermediário, como no Brasil c na generalidade da América Latina. Essesmovimentos tiveram um papel especificonocontexto da "Guerra Fria", constituindo uma espécie de "guerrilha ideológica auxiliar" da UniáoSoviética, da última fase de Stálin a Brezhnev, Mas ao custo da perda da consciéncia da própria realidade, do adensamento da alienaçāo dentro dessas sociedades. Oque tanto mais se acentuou quanto, nessas sociedades, persistiam c persistem, ainda, muitos elementos de uma concepçio mágica do mundo, que se manifesta, predominantemente, pela grande dificuldade de compreender condiçōes de escassez e de raciocinar em termos de causalidade objetiva. Uma das noçōes mágicas primitivasé o maná - oalimento que vemdo céu, que é fornecido sem contrapartida "operacional", sem trabalho ou apropriaçâo, simplesmente como dom supranatural-quando muito com uma intermediação invocatória. É é interessante recordar, a propósito, que Marx jamis demonstrou um entendimentoclaro do fenómenoda escassez economica, que acreditava estar resolvido a priori pelos avanços da tecnologia incorporados no capitalismo.

OBrasil atual oferece-nos um surprecndente fundo de pensamento mágico. A tónica do discurso políticoparlamentarainda é, cm grande parte, invocatória da concessiode favores, privilégios, recursos, para todas as clientelas que, de algum modo, consigam expressar com certa ênfase as suas demandas. Ocritério nảo ćo do usoalternativo dos recursos - é simplesmente o do uso de recursos: identificada uma demanda, reclama-se a correspondente doação de meios. Combina-se, assim, a concepção mágica do mundo com oformalismo politico-jurídico ibérico-colonial numa fórmula que poderíamos chamar de "maná por decreto".

As dimensöes colossais do país, a que aludimos de início, tem como um dos seus efeitos facilitar a convivència dos contrarios, pela justaposição de várias realidades que, $\mathrm{cm}$ si mesmas, seriam pouco com. patibilizáveis: um país moderno c outro periférico, uma simultaneidade de traços culturais que vảo da Idade da Pedra ao mais densenraizadocosmopolitismo. Numerusos paises $\mathrm{cm}$ desenvolvimento, $\mathrm{e}$ alguns dos mais importantes da América Latina, confrontados com os limites das suas possibilidades, jâ oplaram por integrar-sc mais completamente no sistema econômico internacional e deixar maior liberdade de escolha, no plano interno. aos seus cidadäos, mesmo a riscode sacrificar os mitos de um paraísoterrestre, náo muito distante, pela måodo Estado. Mitos, é certo, em relação aos quais poderia parafrasear-se "o rei está nu". No Brasil, o "arrasto" ideológico, a inércia dos paradigmas da transformaçāo do mundo são muito consideráveis. Numerosos grupos não pensam ainda em dá-los por depreciados e amortizados, algo sempre muito difícil tratando-se de idéias que servem a interesses.

A repercussāo profunda do debate sobre a "modernidade", desde 1989, e a mais recente onda popular de demanda de probidade e eficiência na coisa pública podem ter incluído um componente de moda, trabalhado pelas massmedia, mas representam valores fundamentais da sociedade. Talvez nem todos possam identificar claramente os elementos da falsa consciéncia brasilcira, que nos traz de volta permanentemente aos mesmos equívocos, ì repeti. çăo de palavras de ordem e trivialidades que se fingem de proposiçóes com sentido real e, com isso, ocupam com um enchimento sem substincia significante o espaço interior da indagação sobre a condiçäo brasilcira Ja em 1930 o povobradava conIra os "carcomidos"; $\mathrm{cm} 1945,54,55,61 \mathrm{c}$ 64 a temática da honestidade inscrevia-se no debatc nacional pela açáo das classes médias; e em 1989 os "marajás" serviram como ofantasma contra oqual se mobilizou a maioria da opiniăo pública c, pela primcira vez de forma muito nitida na hislória do país, o subproletariado, os "descamisados".

Mas ainda que a reação moralista e mesmo a demanda de eficiência na realiza. çâo das tarefas incumbidas ao Estado pos. sam prestar-se a alimentar enganos da opiniăo pública, clas não falsificam a realidade.

Pelocontrário, assinalam já um começo de amadurecimento importante para que o país se dê conta de que jamais conseguirá ter maná por decreto - eque o caminho da cficiĉncia, do máximo avanço matcrial, ć aquele que combina um verdadeiro respeito pela liberdade do individuo com a simultánea e irredutivel exigência de fazer do Estadoum instrumento da sociedade, e năo, o inverso, subordiná-la à intermediaçáodos que sc intitulam aureolados monopolistas do saber de açảo e de salvaçảo. 